\title{
Functional structure of the landscape and seed dispersal of Araucaria angustifolia in Canoas River Basin (Southern Brazil)
}

\author{
Estructura funcional del paisaje y dispersión de semillas de Araucaria angustifolia \\ en la cuenca del río Canoas (Sur de Brasil)
}

\author{
Amanda Köche Marcon ${ }^{\text {a*}}$, Gisley Paula Vidolin ${ }^{\text {a, }}$, Daniela Biondi ${ }^{\mathrm{b}}$ \\ *Corresponding author: a Federal University of Paraná, Graduate Program in Forestry, \\ Av. Prefeito Lothário Meissner, 632, Curitiba, Paraná, Brazil, amandakoche@gmail.com \\ ${ }^{\mathrm{b}}$ Federal University of Paraná, Department of Forest Sciences, Curitiba, Paraná, Brazil.
}

\begin{abstract}
SUMMARY
Araucaria angustifolia is one of the main species of the Mixed Ombrophilous Forest and has been threatened by extinction. Additionally, a low number of regenerating individuals can be seen in forest remnants. For these reasons, this study aimed at evaluating the functional structure of Canoas River Basin (state of Santa Catarina, Brazil) using landscape ecology metrics, and at verifying whether or not the proximity between remnants is compatible with this species displacement of the main dispersers. Thus, a landscape structure analysis was performed using metrics of area, shape, edge and connectivity of habitat fragments based on satellite images. Landscape metrics were related to maximum distances of displacement of dispersers and to effective dispersion distance based on a genetic estimate derived from secondary data. Results indicate that Canoas River Basin has natural vegetation cover in $19.6 \%$ of its territory and is highly fragmented. A total of $80.8 \%$ of the fragments have an area smaller than 50 ha. The proximity between patches concerning the mean displacement of dispersers $(87 \mathrm{~m})$ is zero for $100 \%$ of fragments. The proximity is zero in $43.5 \%$ landscape, considering the effective seed dispersion based on the genetic estimate of dispersion distance. Therefore, the connectivity between fragments is very low, which may justify the fact that this species is often not found in the regenerating components of forest inventories.
\end{abstract}

Key words: landscape ecology, connectivity, forest fragmentation, Brazilian pine, landscape metrics.

\section{RESUMEN}

Una de las principales especies de los bosques mixtos, Araucaria angustifolia, está en peligro de extinción y también tiene un bajo número de individuos en regeneración. Por estas razones, el objetivo de este estudio fue evaluar, a través de métricas de ecología del paisaje, la estructura funcional de la cuenca del río Canoas, SC, Brasil, y verificar si la proximidad entre los remanentes es compatible con el desplazamiento de los principales dispersores de la especie. Para esto, se utilizaron métricas de área, forma, borde y conectividad de fragmentos de hábitat, utilizando imágenes satelitales. Las métricas del paisaje se relacionaron con las distancias máximas de desplazamiento de los dispersores y con la distancia de dispersión efectiva de la estimación genética, derivada de datos secundarios. Los resultados obtenidos indican que la cuenca del río Canoas tiene una cubierta de vegetación natural en el 19,6 \% de su territorio y está altamente fragmentada, con un 80,8 \% de los fragmentos con un área menor a 50 ha. La proximidad entre los remanentes en vista del desplazamiento de los dispersores $(87 \mathrm{~m})$ es nula para el $100 \%$ de los fragmentos. Considerando la medida efectiva de dispersión de semillas a partir de la estimación genética de la distancia de dispersión, en el 43,5\% del paisaje la proximidad es nula. Se puede concluir que la conectividad entre fragmentos es muy baja, lo que puede justificar el hecho de que la especie a menudo no se encuentre en los componentes regenerativos de los estudios forestales.

Palabras clave: ecología del paisaje, conectividad, fragmentación forestal, pino paraná, métricas del paisaje.

\section{INTRODUCTION}

Araucaria angustifolia (Bertol.) Kuntze (Araucariaceae) is a symbolic tree of the Mixed Ombrophilous Forest and was overexploited in a recent past. Currently, it is a threatened species, and its suppression is prohibited (IBAMA 1992). Nonetheless, there are indications that A. angustifolia has often low natural regeneration since regenerating individuals are found in lower proportion contrasted with adult individuals (Chami et al. 2011). In addition, the long-term species perpetuation in the landscape is worrisome due to increasing temperature related to climate change and conversion of natural areas caused by land-use changes (Marchioro et al. 2020).

The seed dispersal of $A$. angustifolia occurs mainly by small mammals, because it depends on animals to carry 
seeds after the pine nut falls (Iob and Vieira 2008). Thus, the effect of landscape functional connectivity plays a crucial role in maintaining the interaction networks between plants and animals, as it can impose barriers and limit pollination and seed dispersal (Hadley and Betts 2011).

Most fragments of the Mixed Ombrophilous Forest are small, having an area of up to 50 hectares (Sevegnani et al. 2013). Therefore, they suffer high anthropogenic pressure. In fragmented landscapes, habitat filters influence propagules availability: isolation decreases the abundance of dispersers and impact vegetation composition (Dea'k et al. 2018). In view of this situation, there is an evident need to develop and apply non-invasive methods to examine the effects of fragmentation on the seed dispersal of $A$. angustifolia at a local scale (Finch et al. 2020), such as those used in satellite image-based landscape ecology and geographic information systems (GIS).

Therefore, this study aimed at evaluating the functional structure of Canoas River Basin (state of Santa Catarina, Brazil) using landscape ecology metrics, and at relating the structure to the seed dispersal of $A$. angustifolia, a species of the Mixed Ombrophilous Forest. It sought to answer the following questions regarding Canoas River Basin: i) How is the landscape structure, especially considering the vegetation cover, degree of fragmentation and connectivity between fragments? and ii) is the proximity between natural remnants compatible with the displacement of the main seed dispersers of A. angustifolia?

\section{METHODS}

The study area is Canoas River Basin, one of the main rivers located in the Hydrographic Region (HR) 4 - Plateau of Lages, in Serrano Plateau of the state of Santa Catarina, comprising 28 municipalities (figure 1).

For the landscape metrics analysis, an inventory of the Atlantic Forest remnants (shapefile) was used. It was provided by the non-governmental organization SOS Mata Atlântica in partnership with National Institute for Space Research (INPE) based on images from the Landsat 8 satellite for 2016, with spatial resolution of $30 \mathrm{~m}$ (SOS Mata Atlântica and INPE 2017), and the Ottocodified Hydrographic Base, provided by National Water Agency of Brazil (ANA 2012) (figure 2). The Atlantic Forest remnants shapefile from SOS Mata Atlântica has two classes of natural areas: forest fragments (Mixed Ombrophilous Forest) and other non-forest natural fragments (Grasslands or "Campos" - figure 1). However, for this study, both were considered as habitat fragments, without distinction.

The landscape ecology analysis was conducted for the fragments and for the whole landscape, considering only habitat fragments (forest remnants and other nonforest natural remnants). Non-forest natural remnants were included because these natural vegetation patches allow the transit of seed dispersers. To assess landscape structure, the area, shape, edge and connectivity metrics were calculated (table 1). They enabled the assessment of fragments size and shape, relating them to the edge effect

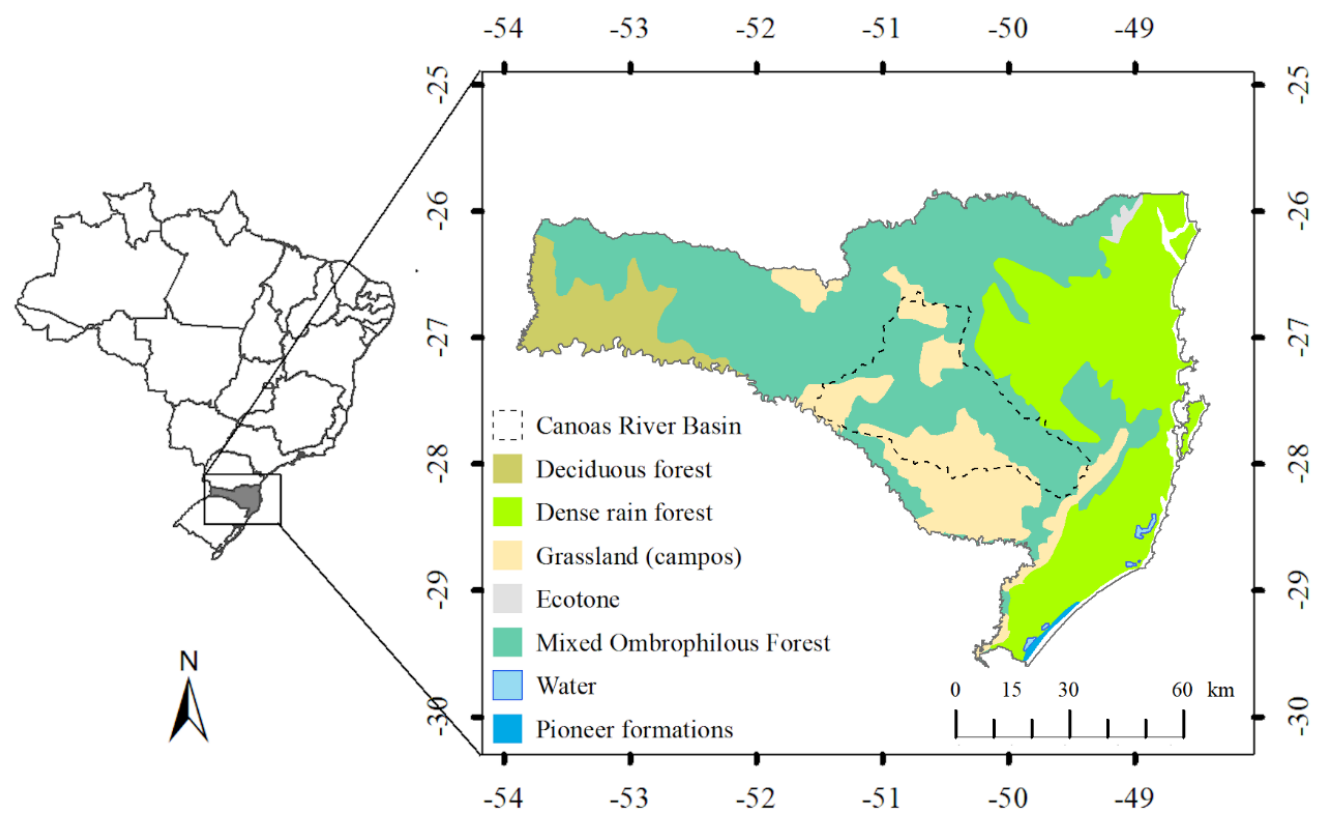

Figure 1. Location map of Canoas River Basin and phytogeographic formations in the state of Santa Catarina, Brazil.

Mapa de ubicación de la cuenca del río Canoas y formaciones fitogeográficas en el estado de Santa Catarina, Brasil. 


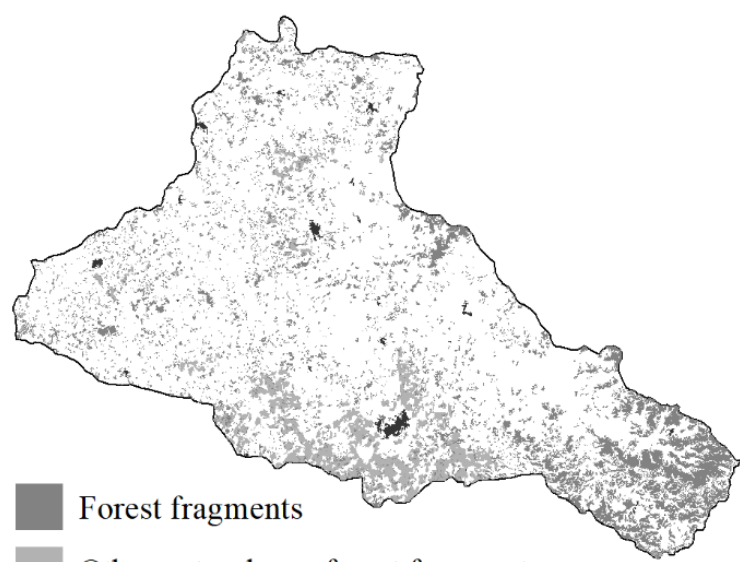

Other natural non-forest fragments

Urban area

Figure 2. Atlantic Forest remnants in Canoas River Basin (Santa Catarina, Southern Brazil) provided by SOS Mata Atlântica and National Institute for Space Research (INPE). Based on images from the Landsat 8 satellite (2016, spatial resolution of $30 \mathrm{~m}$ ) (SOS Mata Atlântica and INPE 2017).

Remanentes del bosque atlántico en la cuenca del río Canoas (Santa Catarina, sur de Brasil) proporcionados por SOS Mata Atlântica y el Instituto Nacional de Investigaciones Espaciales (INPE). Basado en imágenes del satélite Landsat 8 (2016, resolución espacial de 30 m). and proximity and allowing inferences about the landscape connectivity.

To assess the core areas, an edge effect of $50 \mathrm{~m}$ was considered, based on other studies performed in the region that evaluated the environmental, floristic and structural conditions at different edge distances (Guidini et al. 2014, Dalla Rosa et al. 2015). SHAPE, CORE, and CAI metrics were evaluated by fragment size classes $(<5$ ha, 5-50 ha, 50-100 ha, and >100 ha) using boxplots.

For connectivity metrics, a standard search radius of $1,000 \mathrm{~m}$ was used, which is a commonly measure for landscape ecology studies. In addition, to check if there were neighboring fragments compatible with the displacement distances of the main seed dispersers of $A$. angustifolia, other two search radii were considered (table 2). The maximum values found in each study were used, seeking to not underestimate animals' displacement capacity since the methodologies of the studies were different. Seed dispersal distance data from the genetic structure were also employed, based on studies that assessed seed dispersal distances regarding the location of mother trees and regenerating individuals. Based on the maximum values found in each study, two average distances were calculated: 1) for the displacement distances of dispersers; and 2) for seed dispersal distances based on genetic proximity.

Table 1. Metrics for fragments and landscape of Canoas River Basin, state of Santa Catarina, Brazil.

Métricas para fragmentos y paisaje de la cuenca del río Canoas, estado de Santa Catarina, Brasil.

\begin{tabular}{cccl}
\hline Category & Metric & Range & \multicolumn{1}{l}{ Description } \\
\hline Area & AREA & $>0$ & Fragment area (ha). \\
\hline Shape & SHAPE & $\geq 1$ & Fragment shape. The closer to 1, the more regular the shape. \\
\hline & CORE & $\geq 0$ & Core area considering edge size (ha). \\
Core area & NCORE & $\geq 0$ & Number of core areas. \\
& CAI & $0 \leq \mathrm{CAI}<100$ & Fragment percentage corresponding to the core area. \\
& ENN & $>0$ & Euclidean nearest neighbor distance (m). \\
Connectivity & PROX & $\geq 0$ & $\begin{array}{l}\text { Proximity index. When it is equal to zero, there are no } \\
\text { neighbors in the search radius; it rises as the neighborhood is }\end{array}$ \\
& increasingly occupied by patches of the same type.
\end{tabular}


Table 2. Displacement distances for the dispersers of $A$. angustifolia used in this study, according to studies developed in the phytogeographic region of the Mixed Ombrophilous Forest.

Distancias de desplazamiento para los dispersores de $A$. angustifolia utilizados en este estudio.

\begin{tabular}{|c|c|c|c|c|}
\hline \multicolumn{3}{|c|}{ Sources } & \multirow{2}{*}{$\begin{array}{c}\begin{array}{c}\text { Maximum } \\
\text { distance }(\mathrm{m})\end{array} \\
26.7\end{array}$} & \multirow[t]{2}{*}{$\begin{array}{c}\text { Average } \\
\text { distance }(\mathrm{m})\end{array}$} \\
\hline \multirow{8}{*}{$\begin{array}{l}\text { Dispersers displacement } \\
\text { distances }\end{array}$} & & Lamberts (2003) & & \\
\hline & Small rodents & Marques et al. (2011) & 70 & \multirow{7}{*}{$87^{\mathrm{a}}$} \\
\hline & & Nicola (2009) & 225 & \\
\hline & \multirow{3}{*}{ Jays } & Anjos (1991) & 80 & \\
\hline & & Kindel (1996) & 100 & \\
\hline & & Solórzano-filho (2001) & 120 & \\
\hline & Agouti & Lamberts (2003) & 50 & \\
\hline & Squirrels & Bordignon and Monteiro-Filho (2000) & 25 & \\
\hline \multirow{3}{*}{\multicolumn{2}{|c|}{$\begin{array}{l}\text { Seed dispersal distances (genetic proximity of } \\
\text { mother tree and regenerants) }\end{array}$}} & Cristofolini (2013) & 237 & \multirow{3}{*}{$287^{\mathrm{b}}$} \\
\hline & & Bittencourt and Sebbenn (2007) & 291 & \\
\hline & & Sant'anna (2011) & 334 & \\
\hline
\end{tabular}

${ }^{\text {a }}$ Based on the average of all dispersers displacement distances.

${ }^{\mathrm{b}}$ Based on the average of all seed dispersal distances considering genetic proximity of mother trees and regenerating individuals.

Euclidean nearest neighbor distance (ENN) was assessed using a frequency histogram, and PROX metric was assessed using absolute and relative frequencies in different classes.

Geoprocessing activities were performed using ArcGis 10.3 software (ESRI 2013), and landscape metrics were calculated using Fragstats 4.2 software (McGarigal et al. 2012). Charts were constructed using the $R$ programming language (R Core Team 2020).

\section{RESULTS}

Landscape structure. A total of 3,436 patches of habitat were recorded in Canoas River Basin, which corresponds to an area of 291,391 ha. Considering the total calculated area of the basin in this study $(1,488,846 \mathrm{ha}), 19.6 \%$ are habitat areas, i.e. forest remnants and other non-forest natural remnants. Of the total number of patches in Canoas River Basin, $80.8 \%$ have an area smaller than 50 ha (table 3, figure 3). It could be found that fragments larger than 50 ha occupy $16.4 \%$ of the landscape when assessing the proportion of habitat areas in relation to the total area of the Canoas River basin. The landscape percentage composed of the largest fragment (LPI) is only $1.9 \%$.

The mean value obtained for the landscape shape index (SHAPE) was 1.87, indicating that, in general, fragments are little shredded and presented shapes similar to a rectangle. Fragments with shape metrics of up to 1.5 correspond to $36.9 \%$ of the total value; shape between 1.5 and 2 to $34.3 \%$, and shape from 2 to $28.8 \%$. Regarding the
Table 3. Number of patches of habitat (forest natural remnants) by area size class in Canoas River Basin, state of Santa Catarina, Brazil.

Número de fragmentos de hábitat (bosques naturales remanentes) por clase de tamaño del área de la cuenca del río Canoas, estado de Santa Catarina, Brasil.

\begin{tabular}{ccccc}
\hline $\begin{array}{c}\text { Class } \\
\text { (ha) }\end{array}$ & Number & $\begin{array}{c}\% \text { in } \\
\text { class }\end{array}$ & $\begin{array}{c}\text { Total area } \\
\text { (ha) }\end{array}$ & $\begin{array}{c}\text { Occupation in the } \\
\text { landscape (\%) }\end{array}$ \\
\hline$<5$ & 266 & 7.7 & 783.5 & 0.1 \\
$5-50$ & 2,513 & 73.1 & $47,040.3$ & 3.2 \\
$50-100$ & 349 & 10.2 & $23,860.8$ & 1.6 \\
$>100$ & 308 & 9.0 & $219,706.3$ & 14.8 \\
\hline Total & 3,436 & 100.0 & $291,390.8$ & 19.6 \\
\hline \multicolumn{2}{l}{ Total basin area (ha) } & & \multicolumn{3}{c}{$1,488,846.0$} \\
\hline
\end{tabular}

size classes of the fragments, the most important variation in shape is in fragments with the largest size (> $100 \mathrm{ha})$, whereas the smaller ones $(<5 \mathrm{ha})$ have a shape close to 1 and are more regular (figure 4A). Fragments with shape metrics above 4 are the largest in relation to the total area. Even though they have a highly irregular shape, they also correspond to the largest core areas of Canoas River Ba$\sin$ (figures $4 \mathrm{~B}$ and $4 \mathrm{C}$ ). The largest fragments (areas of 28,000 and 21,000 hectares) had very high values for shape metrics (10 and 17), although they were also the patches 


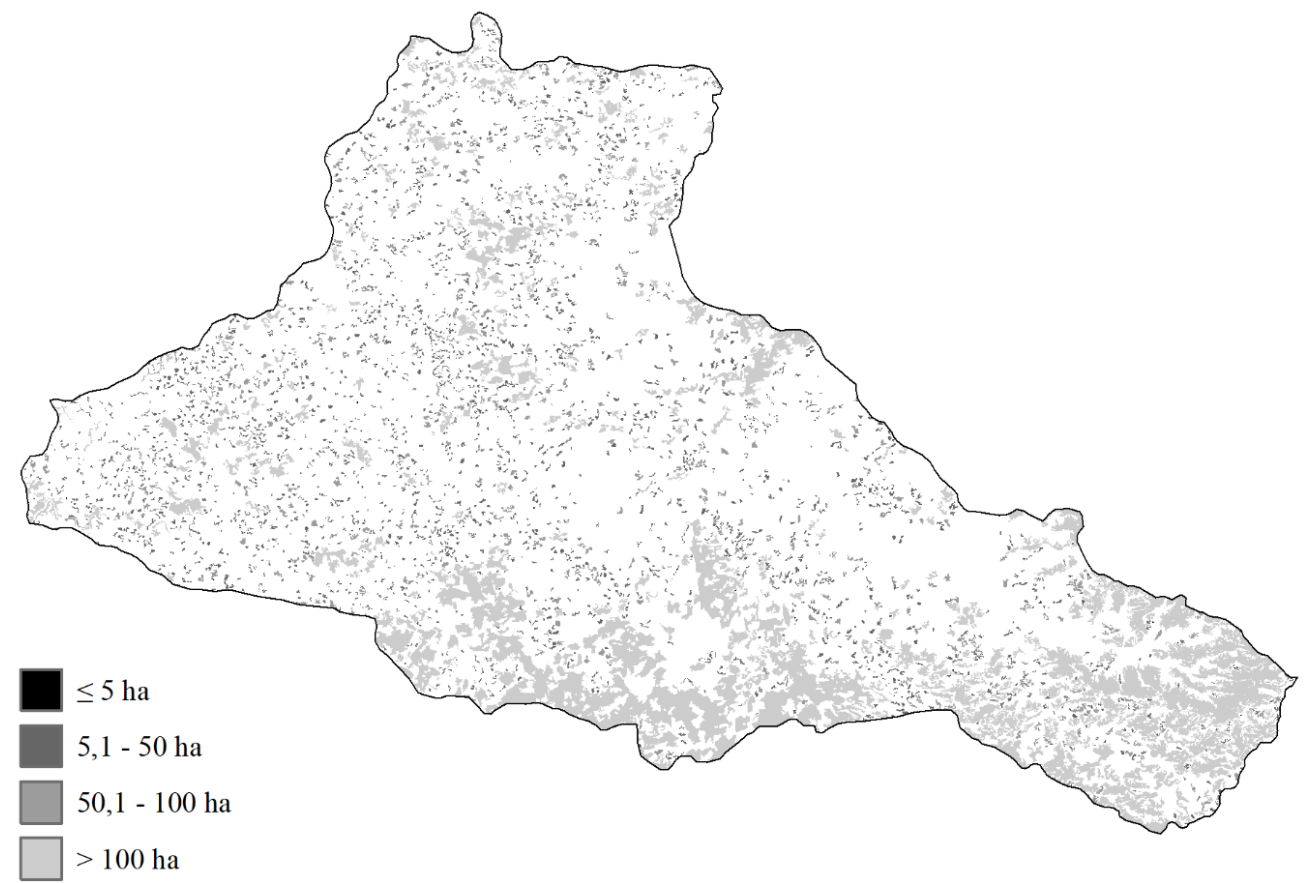

Figure 3. Size classes of habitat fragments in Canoas River Basin, state of Santa Catarina, Brazil.

Clases de tamaño de fragmentos de hábitat en la cuenca del río Canoas, estado de Santa Catarina, Brasil.

with the highest proportions of core areas, corresponding to 91 and $83 \%$ of the total area, respectively.

For the total area (fragments with forest remnants and other non-forest natural remnants) of Canoas River Basin, the core area (CORE) was of $2,173.2 \mathrm{~km}^{2}$. This result implies a reduction of $25.4 \%$ when compared to the total area. Among the fragments, 46 had no core area, i.e., when the edge size was applied, the whole fragment consisted of an edge habitat. Based on the metric that calculates the percentage of a fragment that corresponds to the core area (CAI), it could be noticed that $61 \%$ of fragments have less than $50 \%$ core area in relation to the total area (2,091 fragments).

Connectivity between fragments and relation to seed dispersal of A. angustifolia. Canoas River Basin has a density of 0.23 fragments per 100 hectares. The mean proximity index (PROX) found for a generalist search radius $(1,000$ m) was 344, and the nearest neighbor distance (ENN) was $362 \mathrm{~m}$. The distance to the nearest and most frequent fragment was 100 to $200 \mathrm{~m}$ (figure 5).

Using a search radius of $87 \mathrm{~m}$, which corresponds to the mean displacement distance of the dispersers of $A$. angustifolia considered in this study, the proximity index was equal to 0 (zero) for all fragments. This result suggests that there are no neighboring fragments within this radius of distance throughout Canoas River Basin. For seed dispersal distance considering genetic proximity and applying a search radius of $287 \mathrm{~m}, 1,495$ fragments with a proximity index equal to 0 (zero) were found (table 4 ). This number indicates that $43.5 \%$ of the remaining fragments do not have a neighbor within the seed dispersal limit of $A$. angustifolia, considering the genetic distance. Equivalently, results of the metric that measures the nearest neighbor distance $(\mathrm{ENN})$ indicate that 1,941 fragments have at least one neighbor within the seed dispersal limit, considering the distance between mother and regenerating trees.

\section{DISCUSSION}

Landscape structure. Considering the total number of fragments, Canoas River Basin presents the same reality as those of Mixed Ombrophilous Forest as a whole and the Atlantic Forest biome, having approximately $80 \%$ of the forest remnants with an area of less than 50 ha (Ribeiro et al. 2009, Sevegnani et al. 2013). The large number of small fragments indicates high degree of landscape destruction and, consequently, a more important edge effect. Likewise, the landscape percentage composed of the largest fragment (LPI) was exceptionally low, demonstrating the intense fragmentation since the largest fragment comprises only a small area in relation to the total landscape. These results already indicate that seed dispersal may be impaired as many small fragments may not be sufficient for long-term survival of large vertebrates, and the lack of 
connectivity between the remnants may hinder seed dispersal of the local flora, particularly those with large seeds (Bueno et al. 2013).

Fragments with an area larger than 50 ha are located mainly in the South and Southeast regions of the basin. In
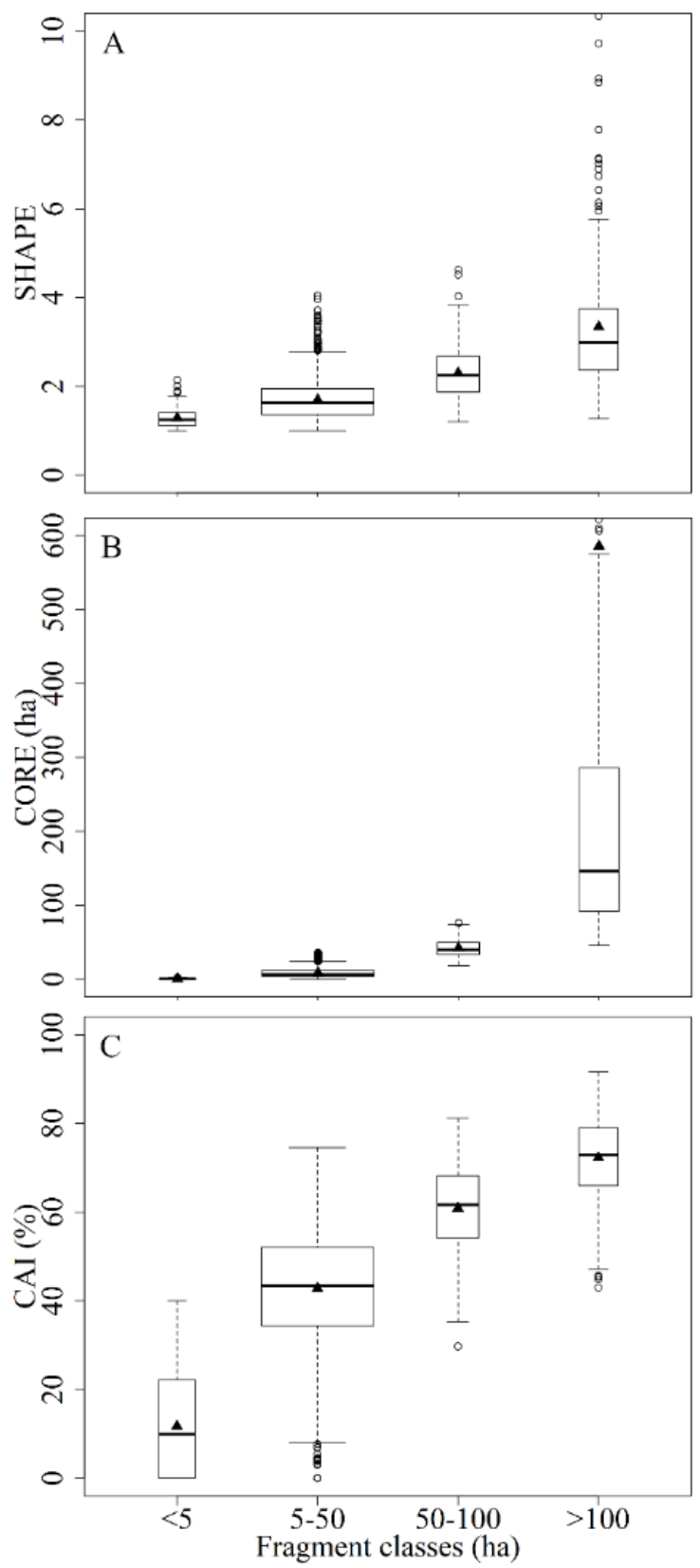

Figure 4. Boxplots for the metrics of SHAPE (A), CORE (B) and CAI (C) by fragment size class from Canoas River Basin, state of Santa Catarina, Brazil. Closed triangles correspond to the mean and open circles represent the outliers.

Gráficos de caja para las métricas de SHAPE (A), CORE (B) y CAI (C) por clase de tamaño de fragmento de la cuenca del río Canoas, estado de Santa Catarina, Brasil. Los triángulos cerrados corresponden a la media y los círculos abiertos representan los valores atípicos. the South, it comprises the municipalities of Campo Belo do Sul, Capão Alto, Lages and Painel. In the Southeast, the fragments are mainly in the following municipalities close to Serra Geral: Urubici, Bom Retiro and Rio Rufino. The proximity to the mountain range may have led to better conservation in this region since the larger slopes

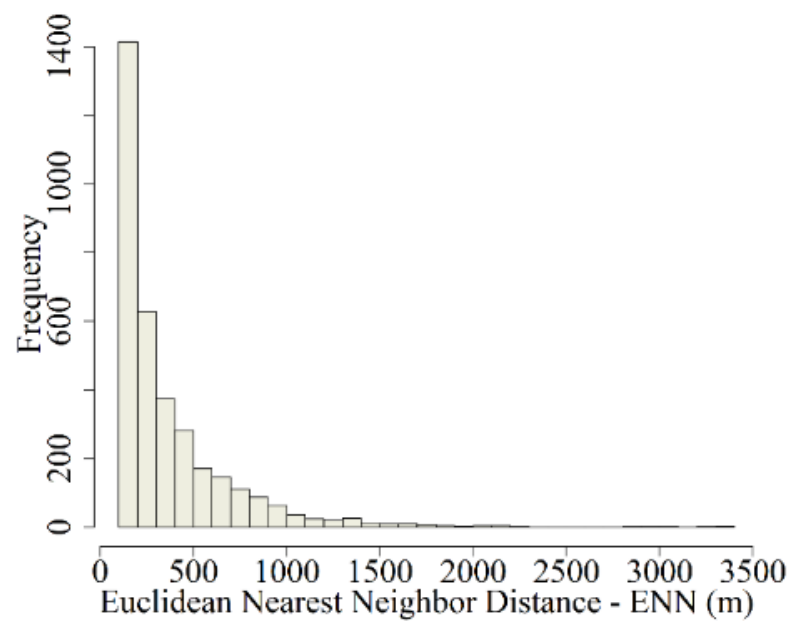

Figure 5. Frequency histogram of the Euclidean nearest neighbor distance (ENN) for Canoas River Basin, state of Santa Catarina, Brazil.

Histograma de frecuencia de la distancia euclidiana al vecino más cercano (ENN) para la cuenca del río Canoas, estado de Santa Catarina, Brasil.

Table 4. Frequencies of the PROX connectivity metric for Canoas River Basin fragments, state of Santa Catarina, Brazil $(\mathrm{AF}=$ absolute frequency; $\mathrm{RF}=$ relative frequency $)$.

Frecuencias de la métrica de conectividad PROX para los fragmentos de la cuenca del río Canoas, estado de Santa Catarina, Brasil $(\mathrm{AF}=$ frecuencia absoluta; $\mathrm{RF}=$ frecuencia relativa $)$.

\begin{tabular}{ccc}
\hline \multirow{2}{*}{ PROX } & \multicolumn{2}{c}{$\begin{array}{c}\text { Seed dispersal (mother and regenerating } \\
\text { tree }(287 \mathrm{~m})\end{array}$} \\
\cline { 2 - 3 } & $\mathrm{AF}$ & $\mathrm{RF}(\%)$ \\
\hline 0 & 1495 & 43.5 \\
$0.1-200$ & 1660 & 48.3 \\
$200.1-400$ & 48 & 1.4 \\
$400.1-600$ & 35 & 1.0 \\
$600.1-800$ & 22 & 0.6 \\
$800.1-1000$ & 21 & 0.6 \\
$>1000$ & 155 & 4.5 \\
\hline Total amount of & 3436 & 100 \\
fragments & & \\
\hline
\end{tabular}


found there may hinder the processes of occupation by man. Land use for economic purposes is preferably done in less sloping areas and at lower altitudes, leading to a more drastic reduction in forest cover in these situations, while more remote and hard-to-reach areas usually have higher vegetation cover (Cunha et al. 2012).

Regarding shape, fragments with a shape index above 2 were observed, reaching values such as 10 and 17 . These fragments with more irregular shape are also those of larger total area and core area, contrary to what was expected. Shape index is influenced by the fragment size and is expected to commonly decrease as the size increases (Turner et al. 2001). Nevertheless, according to the results obtained in this study, even large fragments can have quite complex shapes and may suffer important effects of surrounding matrix. Perhaps, due to the type of land use of neighboring fragments, such as urban area or agriculture, these large fragments are shredded. However, the composition of fragments with large areas can be highly influenced by their shape and edge effect, factors that are often considered more important than the area itself (Didham and Ewers 2012). Ewers and Didham (2007) found that large fragments with highly complex shape can have $80 \%$ of their diversity reduced when compared to smaller circular fragments, a result of the dominance of groups of species that are tolerant to the edge, which impairs the presence of demanding species in shade.

On the other hand, it could be observed that some very small fragments have no core area, according to the edge size adopted. Ferreira et al. (2016) assessed a fragment in the region of Mixed Ombrophilous Forest and concluded that it did not present variations in its organization, structure and relative participation of regeneration guilds in the arboreal community of the edge-interior gradient. Similar result are described by Ferreira et al. (2016), which added to those results on the core area metrics found in this study, suggests that, in fact, some of Mixed Ombrophilous Forest fragments are composed entirely of a habitat with edge characteristics mainly due to the size, shape and large anthropization of the matrix.

Connectivity between fragments and relation to seed dispersal of A. angustifolia. Connectivity between remnants in Canoas River Basin is low, and considering the displacement of the main dispersers of A. angustifolia, it could be inferred that these animals' walking between fragments is quite difficult due to the distance between them and the non-forest matrix. Considering that the seed dispersal of $A$. angustifolia by small rodents is limited to a mean displacement distance of $107 \mathrm{~m}$, and by jays, to $100 \mathrm{~m}$ - according to studies conducted in the phytogeographic region-, and that the mean nearest neighbor distance was less than or equal to the movement of these dispersers in only 314 fragments, i.e., $91 \%$ of cases, there is no connectivity between remnants for these classes of dispersers. As for the seed dispersal by agouti and squirrels, considering the dis- placement distances of 50 and $25 \mathrm{~m}$ respectively, the connectivity between fragments is inexistent since there are no nearby fragments within this limit. If the displacement of dispersers between fragments is difficult, and therefore possibly occurs less frequently, the seeds of this species will likely have greater difficulties of establishment due to factors such as competition and predation. For plants, external factors, such as abundance and disperser behavior, habitat quality and quantity, and interactions between these elements, influence the movement of propagules in ecological and evolutionary time (Damschen et al. 2008).

The large distances between the remnants may justify the low occurrence of $A$. angustifolia regenerants detected in the Mixed Ombrophilous Forest (Chami et al. 2011). Cain et al. (2000) claim that landscape fragmentation can cause populations of many plant species to be spatially isolated from each other, often by hundreds of meters or more. The authors also suggest that most plant seeds do not go far, often only one or a few meters, hindering the reach of new areas by propagules even more. A previous study has found that human interferences as fragmentation and selective logging have had negative effects on the seed disperser communities and the natural availability of seeds of $A$. angustifolia, which reduces seed survival and recruitment (Brocardo et al. 2018). Their results indicated that recruitment has decreased in mean fourfold in forest fragments in relation to continuous forests, suggesting a scenario with low seed dispersal effectiveness on fragmented landscapes.

It is worth mentioning that the edge effect distance considered was $50 \mathrm{~m}$, which makes it impossible for very small fragments to be considered in this metric. However, depending on the landscape matrix, the existence of these small remnants can assist in the displacement of dispersers between larger patches, serving as stepping stones or trampolines.

In view of the genetic estimates of seed dispersal-i.e., a measure of "effective seed dispersal" since it allows to accurately identify the distance between the mother tree and its regenerants (Cain et al. 2000) -, the proximity to other remnants is zero for almost half of the fragments. Even in an optimistic scenario, in which seed dispersal is effective in half the landscape, the situation of the species is worrisome. Assuming that the seed is dispersed, there is still a high probability that it will be degraded or consumed by other animals before germinating; or even, the seedling may suffer from the trampling of cattle, common practice in the forest remnants of the region. For such reasons, both awareness and preservation of the species, as well as commitment to the creation of conservation units that act as connectors of larger fragments are necessary as they can assist in the movement of dispersers of this species.

\section{CONCLUSIONS}

From the results of this study, it can be inferred that Canoas River Basin has a high degree of fragmentation, having a large proportion of small fragments (less than 5 
ha of area). In comparison with the Atlantic Forest biome, the vegetation cover is higher than average, although the number of fragments smaller than 50 ha is compatible with the studies for this biome.

Considering the displacement distance of the main dispersers of $A$. angustifolia, connectivity and proximity between fragments are very low, which may explain the fact that this species is often not found in the regenerating components of forest inventories. On the other hand, considering the results based on genetic proximity and using distance data between the mother tree and regenerating individuals, it can be concluded that a connection would be possible in more than $50 \%$ of fragments. Therefore, other factors may be interfering with the low regeneration of the species, e.g., seed predation. Actions such as the creation of small conservation units and the preservation of ciliary areas that connect habitat fragments can help in increasing the regeneration of the species.

\section{ACKNOWLEDGEMENTS}

The authors would like to thank Academic Publishing Advisory Center (Centro de Assessoria de Publicação Acadêmica, CAPA) of Federal University of Paraná (UFPR) for assistance with English language translation and editing. We also thank Brazilian Research Council (CNPq) for the $\mathrm{PhD}$ grant to the first author (process 140849/2015-7).

\section{REFERENCES}

ANA (Agência Nacional de Águas, BR). 2012. Bacias Hidrográficas Ottocodificadas (Níveis Otto). Accessed 21 feb. 2018. Available at http://metadados.ana.gov.br/geonetwork.

Anjos L. 1991. O ciclo anual de Cyanocorax caeruleus em floresta de araucária (Passeriformes: Corvidae). Ararajuba 2(1): 19-23.

Bittencourt JVM, AM Sebbenn. 2007. Patterns of pollen and seed dispersal in a small, fragmented population of the windpollinated tree Araucaria angustifolia in southern Brazil. Heredity 99(6): 580-591. DOI: 10.1038/sj.hdy.6801019

Bordignon M, ELDA Monteiro-Filho. 2000. O serelepe Sciurus ingrami (Sciuridae: Rodentia) como dispersor do pinheiro do Paraná Araucaria angustifolia (Araucariaceae: Pinophyta). Arquivos de Ciências Veterinária e Zoologia da UNIPAR 3(2): 139-144.

Brocardo CR, F Pedrosa, M Galetti. 2018. Forest fragmentation and selective logging affect the seed survival and recruitment of a relictual conifer. Forest Ecology and Management 408: 87-93. DOI: 10.1016/j.foreco.2017.09.046

Bueno RS, R Guevara, MC Ribeiro, L Culot, FS Bufalo, M Galetti. 2013. Functional redundancy and complementarities of seed dispersal by the last neotropical megafrugivores. PloS one 8(2): e56252. DOI: 10.1371/journal.pone.0056252

Cain ML, BG Milligan, AE Strand. 2000. Long-Distance Seed Dispersal in Plant Populations. American Journal of Botany 87(9): 1217-27. DOI: 10.2307/2656714

Chami LB, MM Araújo, SJ Longhi, P Kielse, AD Lúcio. 2011.
Mecanismos de regeneração natural em diferentes ambientes de remanescente de Floresta Ombrófila Mista, São Francisco de Paula, RS. Ciência Rural 41(2): 251-259. DOI: 10.1590/S0103-84782011000200012

Cristofolini C. 2013. Dinâmica da diversidade genética de Araucaria angustifolia (Bertol.) Kuntze em paisagem de campo no estado de Santa Catarina. Science Master Thesis. Florianópolis, Brazil. Universidade Federal de Santa Catarina. 93 p.

Cunha JEBL, IAA Rufino, BB Silva, IB Chaves. 2012. Dinâmica da cobertura vegetal para a Bacia de São João do Rio do Peixe, PB, utilizando-se sensoriamento remoto. Revista Brasileira de Engenharia Agricola e Ambiental 16(5): 539-548. DOI: 10.1590/S1415-43662012000500010

Dalla Rosa A, AC Silva, P Higuchi, AL Guidini, FR Spiazzi, M Negrini, RD Ansolin, MA Bento, DA Gonçalves, TS Ferreira. 2015. Diversidade e guildas de regeneração de espécies arbóreas na borda de uma floresta nativa em contato com plantio de pínus. Floresta 45(2): 273-280. DOI: $\underline{10.5380 /}$ rf.v45i2.34676

Damschen EI, LA Brudvig, NM Haddad, DJ Levey, JL Orrock, JJ Tewksbury. 2008. The movement ecology and dynamics of plant communities in fragmented landscapes. Proceedings of the National Academy of Sciences 105(49): 1907819083. DOI: $10.1073 /$ pnas.0802037105

Deák, B., O Valkó, P Török, A Kelemen, Á Bede, AI Csathó, B Tóthmérész. 2018. Landscape and habitat filters jointly drive richness and abundance of specialist plants in terrestrial habitat islands. Landscape Ecology 33(7): 1117-1132. DOI: 10.1007/s10980-018-0660-x

Didham RK, RM Ewers. 2012. Predicting the impacts of edge effects in fragmented habitats: Laurance and Yensen's core area model revisited. Biological Conservation 155: 104110. DOI: $10.1016 /$ j.biocon.2012.06.019

Environmental Systems Research Institute (ESRI). 2013. ArcGIS for Desktop: release 10.3. Redlands, CA.

Ewers RM, RK Didham. 2007. The effect of fragment shape and species' sensitivity to habitat edges on animal population size: Contributed papers. Conservation Biology 21(4): 926 936. DOI: $\underline{10.1111 / \mathrm{j} .1523-1739.2007 .00720 . \mathrm{x}}$

Ferreira TS, AK Marcon, B Salami, CCC Rech, AR Mendes, AF Carvalho, FF Missio, F Pscheidt, AL Guidini, RS Dornelles, AC Silva, P Higuchi. 2016. Composição florístico-estrutural ao longo de um gradiente de borda em fragmento de Floresta Ombrófila Mista Alto-Montana em Santa Catarina. Ciência Florestal 26(1): 123-134.

Finch D, DP Corbacho, H Schofield, S Davison, PGR Wright, RK Broughton, F Mathews. 2020. Modelling the functional connectivity of landscapes for greater horseshoe bats Rhinolophus ferrumequinum at a local scale. Landscape Ecology 35(3): 577-589. DOI: 10.1007/s10980-019-00953-1

Guidini AL, AC Silva, P Higuchi, A Dalla Rosa, FR Spiazzi, M Negrini, TS Ferreira, B Salami, AK Marcon, F Buzzi Junior. 2014. Invasão por espécies arbóreas exóticas em remanescentes florestais no Planalto Sul Catarinense. Revista Árvore 38(3): 469-478. DOI: 10.1590/S010067622014000300009

Hadley AS, MG Betts. 2011. The effects of landscape fragmentation on pollination dynamics: absence of evidence not evidence of absence. Biological Reviews 87(3): 526-544. DOI: 10.1111/j.1469-185X.2011.00205.x

Instituto Brasileiro do Meio Ambiente e dos Recursos Naturais 
Renováveis (IBAMA). 1992. Portaria IBAMA No 06-N, de 15 de janeiro de 1992, Ministério do Meio Ambiente. Consulted 13 mar. 2018. Available in http://www.mma.gov.br/ estruturas/179/ arquivos/179 05122008033646.pdf.

Iob G, EM Vieira. 2008. Seed predation of Araucaria angustifolia (Araucariacae) in the Brazilian Araucaria Forest: influence of deposition site and comparative role of small and 'large' mammals. Plant Ecology 198: 185-198. DOI: 10.1007/s11258-007-9394-6

Kindel EAI. 1996. Padrões de dispersão e disposição espacial de Araucaria angustifolia (Bert.) O. Ktze. e suas relações com aves e mamíferos na Estação Ecológica de Aracuri, Esmeralda, RS. Master in Ecology. Porto Alegre, Brazil. Universidade Federal do Rio Grande do Sul.

Lamberts AH. 2003. Predação e sobrevivência de sementes de Araucaria angustifolia (Bert.) Kuntze em áreas de mata nativa e plantação de Pinus eliotii na Floresta Nacional de São Francisco de Paula, RS. Master in Ecology. Campinas, Brazil. Universidade Estadual de Campinas. 165 p.

Marques RV, CV Cademartori, SM Pacheco. 2011. Mastofauna no Planalto das Araucárias, Rio Grande do Sul, Brasil. Revista Brasileira de Biociências 9(3): 278-288. DOI: 10.11606/T.17.2006.tde-01082007-105409

Marchioro CA, KL Santos, A Siminski. 2020. Present and future of the critically endangered Araucaria angustifolia due to climate change and habitat loss. Forestry: An International Journal of Forest Research 93(3): 401-410. DOI: 10.1093/ forestry/cpz066

McGarigal K, Cushman SA, Ene E. 2012. FRAGSTATS v4: Spatial Pattern Analysis Program for Categorical and Continuous Maps. Amherst: University of Massachusetts. Accessed 13 jan. 2020. Available at http://www.umass.edu/ landeco/research/fragstats/fragstats.html.

Nicola PA. 2009. Comunidades de pequenos mamíferos como indicadores de qualidade ambiental no planalto norte catarinense. Forestry Engineer Thesis. Curitiba, Brazil. Univer- sidade Federal do Paraná. 118 p.

R Core Team. 2020. R: A language and environment for statistical computing. R Foundation for Statistical Computing, Vienna, Austria. Accessed $21 \mathrm{dez}$. 2020. Available at https://www.R-project.org/.

Ribeiro MC, JP Metzger, AC Martensen, FJ Ponzoni, MM Hirota. 2009. The Brazilian Atlantic Forest: How much is left, and how is the remaining forest distributed? Implications for conservation. Biological Conservation 142(6): 11411153. DOI: $10.1016 /$ j.biocon.2009.02.021

Sant'Anna CS. 2011. Diversidade genética, estrutura genética espacial e dispersão realizada de pólen e sementes em uma população contínua de Araucaria angustifolia (Bertol.) Kuntze no planalto norte de Santa Catarina. Science Master Thesis. Florianópolis, Brazil. Universidade Federal de Santa Catarina. $89 \mathrm{p}$.

Sevegnani L, AC Vibrans, AL Gasper. 2013. Considerações finais sobre a Floresta Ombrófila Mista em Santa Catarina. In Vibrans AC, L Sevegnani, AL Gasper. DV Lingner eds. Inventário Florístico Florestal de Santa Catarina. Volume III - Floresta Ombrófila Mista. Blumenau, Brazil. Edifurb. p. $275-278$.

Solórzano-Filho JA. 2001. Demografia, fenologia e ecologia da dispersão de sementes de Araucaria angustifolia (Bert.) Kuntze (Araucariaceae), numa população relictual em Campos do Jordão, SP. Ecology Thesis. São Paulo, Brazil. Universidade de São Paulo. 115 p.

SOS Mata Atlântica and INPE (Instituto Nacional de Pesquisas Espaciais, BR). 2017. Atlas dos Remanescentes Florestais da Mata Atlântica: Relatório Técnico Período 2015-2016. Accessed 21 feb. 2018. Available at http://mapas.sosma. org.br/site media/download/atlas 2015-2016 relatorio tecnico 2017.pdf.

Turner MG, RH Gardner, RV O’Neill. 2001. Landscape ecology in theory and practice: pattern and process. New York, USA. Springer. $401 \mathrm{p}$. 
